\title{
RESEARCH
}

Open Access

\section{Effective treatments of jojoba and jatropha hulls to obtain phytochemical compounds for industrial, nutritional, and pharmaceutical uses}

Engy Mohamed Akl ${ }^{1 *}$ D, Fakhriya Said Taha', Samira Saied Mohamed', Suzanne Mohamed Wagdy and Samy Mohamed Abdel Hamid ${ }^{2}$

\begin{abstract}
Background: In the industry, acid and alkali are used to hydrolyze lignocellulosic materials into cellulose and lignin. The cellulose is to be used in several industries such as the production of bioethanol, in the sugar industry, and as carbonaceous materials in place of bleaching agents. On the other hand, the lignin separated from the lignocellulosic materials is used as a rich source of different bioactive materials. Usually, the alkali and acid hydrolysis are carried out at high temperatures. The aim of this study was to carry the extraction by using ultrasound equipment at low temperatures to save the phytochemicals present. This study was designed to investigate the effect of 12 different treatments on the extraction of bioactive compounds from jatropha and jojoba hulls. These bioactive extracts are examined for their phytochemical content, antioxidant, and antibacterial activities. The free and bounded bioactive compounds from jojoba and jatropha hulls were also considered. From our previous work, we reached the conclusion that a single extraction method is not as effective as a mixture of solvents and extraction processes.

Methods: The hulls were ground and sieved. The effects of ultrasound-assisted extraction together with soaking afterwards were investigated. Solvents used were $(1,0.5 \mathrm{~N} \mathrm{HCl}),(1,0.5 \mathrm{~N}-\mathrm{NaOH})$, and $(70 \mathrm{ml}$ ethanol mixed with $30 \mathrm{ml}$ of $(1,0.5) \mathrm{N} \mathrm{HCl}$ or $\mathrm{NaOH})$ and then soaking to reduce the temperature and to enhance the process in order to hydrolyze lignin. The phenolic compounds, flavonoids, and saponins in each extract were determined, and their antioxidant activities were evaluated. Three antioxidant activity methods were applied for each extract: hydrogen peroxide $\left(\mathrm{H}_{2} \mathrm{O}_{2}\right)$ radical scavenging activity, DPPH, and total reducing capability.

Results: Bioactive compounds in their natural form were found to possess high antioxidant activities exceeding that of $\mathrm{BHT}$. The $\mathrm{NaOH}$ proved to have a great power for the extraction of phytochemical compounds with elevated antioxidant activities from jojoba, while $(1,0.5 \mathrm{~N}) \mathrm{HCl}$ with ethanol (30-70\%) concentrations extracted phytochemicals with high antioxidant activity from jatropha.

Conclusion: (A) A simple method for the extraction of flavonoid, phenolic, and saponin compounds from jojoba and jatropha hulls with different activities has been developed. This method utilized a small amount of solvent and less energy. The bioactive extracts can be used in the pharmaceutical industry. (B) Introduce different structure of bioactive compost extracts from jojoba and jatropha hulls through hydrolyses of lignocellulolytic hulls and then the residue will be ready at the same time for multi-uses in industrial purposes.
\end{abstract}

Keywords: Jojoba and jatropha hulls, Ultrasound-assisted extraction, Phenolics, Saponins, Flavonoids, Antioxidant, Anti-bacterial

\footnotetext{
*Correspondence: engy_akl@yahoo.com

'Department of Fats and Oils, National Research Centre, Dokki, Cairo, Egypt

Full list of author information is available at the end of the article
} 


\section{Introduction}

In recent years, industries generate multi-wastes without any commercial value. These wastes could be converted to valuable substances by extraction of high-value compounds that can be applied in different fields such as agricultural, food, and medical industries (Rostagno and Prador 2013). The selection of pretreatment methods was based on its potential yield, its economic assessment, and its influence on the environment (Harmsen et al. 2010).

Lignocellulosic materials are the main abundant renewable biomass on the earth, and most of them resulted from industrial wastes (e.g., oil seeds hulls) and consist of three main compounds: cellulose, hemicellulose, and lignin (Faulon et al. 1994). Cellulose and hemicellulose are polymers with good yield of fermentable sugars and ethanol. Lignin is mainly used for different purposes such as chemicals, heat, and power. The hydrolysis of cellulose and hemicellulose and the process applied to the separation of the lignin fractions into its constituents for market competitive are very important (Harmsen et al. 2010). There are four main types of bonds in the lignocellulose complex (ether bonds, ester bonds, carbon-to-carbon bonds, and hydrogen bonds). These four bonds are the main linkages in the lignocelluloses' structure and connect the different components to form the complex (interpolymer linkages).

Jatropha and jojoba seeds hulls have a hard and blackish hulls, e.g., which is the wall or coat of the seed (Mohammad 2010). Jatropha and jojoba seeds hulls have recently been applied as low-cost materials for the adsorption of a dye, cadmium $\left(\mathrm{Cd}^{2+}\right)$ ions, and zinc ions. Their high lignin content offered good remarkable adsorption capacity and possess bioactive compounds (Wagdy and Taha 2017; El-Hamidi et al. 2016).

Phytochemicals, which are isolated and purified from plants, have recently applied in the medical field due to their antimicrobial and antioxidant properties (Olajire and Azeez 2011; Sticher 2008). The current study presents different structures of bioactive compounds extracted from jojoba and jatropha hulls through hydrolyses of lignocellulolytic hulls and then the residue will be ready at the same time for multi-uses in industrial purposes.

Phenolic compounds and the other bioactive compound extracts from agro-industrial by-products with antioxidant activity have been presented in several plant foods, agricultural by-products, and industrial residues (Schieber et al. 2001). Some of these by-products have been successfully proved as effective sources of antioxidants, anti-microbial, anti-thrombotic, cardioprotective, and vasodilatory applications. Their effects help in defiance against predators and pathogens; they have been reported to be active against a wide range of organisms (Upadhyay 2011).

Phenolic compounds are an essential part of the human diet and are of considerable interest due to their antioxidant properties. It possesses an aromatic ring with one or more hydroxyl groups, and their structures may range from a simple phenolic molecule to a polymer complex (Shahidi and Yeo 2016). Flavonoids are present in natural plants such as legumes, cereals, and other seeds. It consists of three ring structures, with different substitution groups $\left(\mathrm{OH}\right.$ or $\left.\mathrm{CH}_{3}\right)$, which constitute different classes of flavonoids, and it also presents in the soluble and insoluble-bound forms. Bound flavonoids present in oilseeds and others reported in the literature (Sticher 2008; Mohammad et al. 2013).

Flavonoids and phenols, present in Jatropha curcas, are the main group of polyphenolic compounds in plants (Sticher 2008). It exhibits activity against gram-positive bacteria (Meyer et al. 1997) and Streptococcus mutans (He et al. 2006). Bound phenolics and flavonoids can be extracted by different methods such as acid, alkali, and enzymatic hydrolysis to extract strong bioactive compounds as agents against cancer, cardiovascular disease, and inflammation (Shahidi and Yeo 2016).

Saponins are naturally presented in a great number of plant species, algae, and lower marine with surface-active compounds. They can be extracted from different plant parts and seeds. The chemical structure of saponins showed one, two, or three sugar chains attached to the aglycone (tridesmosides or sapogenins). Their chemical properties and biological activity are affected according to hydrolysis process (in the presence of acids/alkali or hydrothermolysis) and storage (Oleszek and Hamed 2010). Milling is very essential in our study. Milling used to reduce size and enhances the enzymatic hydrolysis of the seeds, and also for treatment processes with dilute acid, steam or other lignocellulosic waste materials (Taherzadeh and Karimi 2008). An ultrasound-assisted extraction process is used in natural phytochemical extraction because it involves disruption of the internal cell structure and liberation of intracellular compounds to surrounding medium. Ultrasound-assisted extraction processes reduce time, solvent, and energy when compared to other industrial techniques (Pingret et al. 2013). The utilization of common extraction medium (dis. water, organic solvent, and aqueous organic solvents) may improve the safety concern and sustainability and increases the extraction yield of bioactive compounds (Kua et al. 2015). The obstacles associated with the extraction of bounded phenolic encourage the researchers to discover new cost-effective and sustainable extraction technologies.

This study aims at the extraction of bioactive compound from jojoba and jatropha hulls through hydrolyses of lignocellulolytic substances (Oloyede et al. 2012).

The first aim of this study is using new extraction process, with different mixtures from ethanol mixed with acid or base to introduce important bioactive compounds to be used as natural source and to avoid the 
bad effect of synthetic additives. The second aim is lowering the consumption of non-renewable resources by extraction of polar compounds with great variety of function groups, with low cost suitable for industrial scale and also utilization in the pharmaceutical applications.

\section{Materials and methods Materials}

Jojoba (Jo) and jatropha (Ja) seeds were brought from the local market. All seeds were manually hulled, and the hulls were ground in a coffee mill to obtain a finely divided material suitable for extraction studies. All chemicals were obtained from Sigma Chemical Co.

Test Microorganisms: the test microorganisms used in this study are Escherichia coli (E. coli), Bacillus cereus (B. cereus), and Asprigillus flavus (A. flavus) obtained from the Microbiology Laboratory, the Dairy Science Department of National Research Center.

\section{Methods}

Preparation of jojoba hulls $(\mathrm{JoH})$ and jatrova hulls $(\mathrm{JaH})$ extract: The dried ground $\mathrm{JoH}$ and $\mathrm{JaH}$ were extracted with $100 \%$ water, $70 \mathrm{ml}$ ethanol, and $30 \mathrm{ml}(0.5 \mathrm{~N} \mathrm{HCl}$; $1 \mathrm{~N} \mathrm{HCl} ; 0.5 \mathrm{NaOH} ; 1 \mathrm{~N} \mathrm{NaOH})$, each separately shown in Tables 1 and 2 . The samples $(1 \mathrm{~g})$ were mixed with $30 \mathrm{ml}$ of mixed solvent 1:30 $(w / v)$ three times. All the samples were placed in $100 \mathrm{ml}$ measuring flasks and mixed for $1 \mathrm{~h}$ in a (crest ultrasonic water bath at $38.5 \mathrm{kHz}$ ) at room temperature, followed by soaking in the same solution for $24 \mathrm{~h}$. The extracts of each sample were collected and filtered through filter paper (Whatman No. 1) and completed to starting volume and stored at $-20^{\circ} \mathrm{C}$.

\section{Phytochemical analysis}

\section{Determination of total phenolic extract (TPE)}

The content of phenolic compounds in the hull extracts were determined by Folin-Ciocalteu reagent method according to (Fu et al. 2014) with some modifications. The absorbance was recorded at $765 \mathrm{~nm}$ using a spectrophotometer (T80 UV-vis spectrophotometers). The TPE was obtained from a regression eq. $(\mathrm{R} 2=0.9996)$ and expressed as $\mathrm{mg} / 100 \mathrm{~g}$ dry sample.

\section{Determination of total flavonoid extract (TFE)}

The colorimetric determination of total flavonoid extract (TFE) was performed according to (Kanatt et al. 2011). The same hull extract of total phenolic determination was used for total flavonoid determination. Standard flavonoid solutions were prepared from quercetin as standard solution for calibration curve. The total flavonoid contents were calculated from the standard curve and were expressed as $\mu \mathrm{g} / 100 \mathrm{~g}$ dry sample.
Table 1 Effect of different treatments on the yield of phenolic, flavonoid, and saponin compounds extracted from jojoba hull at room temperature

\begin{tabular}{|c|c|c|c|}
\hline $\begin{array}{l}\text { Treatment } 1 \mathrm{~g} \text { meal:30 } \\
\mathrm{ml} \text { solvent three times, } \\
\text { each time ultrasound } \\
\text { for } 1 \mathrm{~h} \text { then } \\
\text { soaking } 24 \mathrm{~h} \text {. }\end{array}$ & $\begin{array}{l}\text { Phenolic extract } \\
\mathrm{mg} / \mathrm{g} \pm \mathrm{SD}\end{array}$ & $\begin{array}{l}\text { Flavonoid extract } \\
\mu / g \pm S D\end{array}$ & $\begin{array}{l}\text { Saponin extract } \\
\mu / \mathrm{g} \pm \mathrm{SD}\end{array}$ \\
\hline $\begin{array}{l}\text { Ethanol:1 N HCl } \\
70: 30\end{array}$ & $13.4 \pm 0.01$ & $11.7 \pm 0.02$ & $253.94 \pm 0.01$ \\
\hline $\begin{array}{l}\text { Ethanol:0.5 N HCl } \\
70: 30\end{array}$ & $12.9 \pm 0.03$ & $12.6 \pm 0.01$ & $204.95 \pm 0.02$ \\
\hline $\begin{array}{l}\text { Ethanol: } 1 \mathrm{~N} \mathrm{NaOH} \\
70: 30\end{array}$ & $12.7 \pm 0.02$ & $8.1 \pm 0.04$ & $180.72 \pm 0.10$ \\
\hline $\begin{array}{l}\text { Ethanol:0.5 N NaOH } \\
70: 30\end{array}$ & $11.1 \pm 0.20$ & $6.3 \pm 0.03$ & $135.45 \pm 0.01$ \\
\hline $1 \mathrm{~N} \mathrm{NaOH}$ & $47.6 \pm 0.05$ & $27.9 \pm 0.10$ & $431.81 \pm 0.03$ \\
\hline $0.5 \mathrm{~N} \mathrm{NaOH}$ & $37.7 \pm 0.03$ & $19.8 \pm 0.01$ & $504.77 \pm 0.02$ \\
\hline $1 \mathrm{~N} \mathrm{HCl}$ & $1.3 \pm 0.04$ & $1.35 \pm 0.05$ & ND \\
\hline $0.5 \mathrm{~N} \mathrm{HCl}$ & $1.2 \pm 0.10$ & ND & ND \\
\hline $\begin{array}{l}1 \mathrm{~N} \mathrm{NaOH} \text { then } \\
\text { neutralize with } \\
1 \mathrm{~N} \mathrm{HCl}\end{array}$ & $62.0 \pm 0.05$ & $40.0 \pm 0.03$ & $453.6 \pm 0.20$ \\
\hline $\begin{array}{l}0.5 \mathrm{~N} \mathrm{NaOH} \text { then } \\
\text { neutralize with } \\
0.5 \mathrm{~N} \mathrm{HCl}\end{array}$ & $54.8 \pm 0.01$ & $32.8 \pm 0.02$ & $115.93 \pm 0.10$ \\
\hline $\begin{array}{l}1 \mathrm{~N} \mathrm{HCl} \text { then } \\
\text { neutralize with } \\
1 \mathrm{~N} \mathrm{NaOH}\end{array}$ & $2.9 \pm 0.02$ & $4.5 \pm 0.01$ & - \\
\hline $\begin{array}{l}0.5 \mathrm{~N} \mathrm{HCl} \text { then } \\
\text { neutralize with } \\
0.5 \mathrm{~N} \mathrm{NaOH}\end{array}$ & - & - & - \\
\hline
\end{tabular}

Results are mean values of three replicates \pm standard deviation

\section{Determination of total saponin extract (TSE)}

The colorimetric determination of total saponin extracts (TSE) was performed according to Hiai and Nakajima (1976), and the same extract of total phenolic determination was used for total saponin determination. Standard saponin solutions were prepared from diosgenin as standard solution for calibration curve. The total saponin contents were calculated from the standard curve and were expressed as $\mathrm{mg} / 100 \mathrm{~g}$ dry sample.

\section{Evaluation of antioxidant activity of $\mathrm{JoH}$ and $\mathrm{JaH}$ extracts}

For each extract, three series of antioxidant capacity methods were applied, 2, 2-diphenyl-2-picrylhydrazyl (DPPH) radical scavenging activity, hydrogen peroxide $\left(\mathrm{H}_{2} \mathrm{O}_{2}\right)$ scavenging activity, and total reducing capability.

Determination of the free radical-scavenging assay (DPPH*) The DPPH radical has a strong absorbance at $517 \mathrm{~nm}$ due to its unpaired electron and giving the radical a purple color. But upon reduction with an antioxidant, its absorption decreases due to the formation of its nonradical form, DPPH-H (Blois 1958), that was based on the method of (De Ancos et al. 2002) with some 
Table 2 Effect of different treatment on the yield of phenolic, flavonid, and saponin compounds extracted from jatropha hulls at room temperature

\begin{tabular}{|c|c|c|c|}
\hline $\begin{array}{l}\text { Treatment } \\
1 \mathrm{~g} \text { meal: } 30 \mathrm{ml} \text { solvent three times, each time ultrasound } \\
\text { for } 1 \mathrm{~h} \text { then soaking } 24 \mathrm{~h}\end{array}$ & $\begin{array}{l}\text { Phenolic extract } \\
\mathrm{mg} / \mathrm{g} \pm \mathrm{SD}\end{array}$ & $\begin{array}{l}\text { Flavonoid extract } \\
\mu / g \pm S D\end{array}$ & $\begin{array}{l}\text { Saponin extract } \\
\mu / g \pm S D\end{array}$ \\
\hline $\begin{array}{l}\text { Ethanol:1 N HCl } \\
70: 30\end{array}$ & $21.5 \pm 0.01$ & $17.1 \pm 0.03$ & $108.15 \pm 0.20$ \\
\hline $\begin{array}{l}\text { Ethanol:0.5 N HCl } \\
70: 30\end{array}$ & $22.9 \pm 0.04$ & $13.0 \pm 0.05$ & $147.1 \pm 0.10$ \\
\hline $\begin{array}{l}\text { Ethanol:1 N NaOH } \\
70: 30\end{array}$ & $3.1 \pm 0.02$ & ND & $86.192 \pm 0.01$ \\
\hline $\begin{array}{l}\text { Ethanol:0.5 N NaOH } \\
70: 30\end{array}$ & $3.1 \pm 0.05$ & $9.0 \pm 0.01$ & $92.583 \pm 0.15$ \\
\hline $1 \mathrm{~N} \mathrm{NaOH}$ & $13.2 \pm 0.01$ & $10.35 \pm 0.02$ & $68.885 \pm 0.05$ \\
\hline $0.5 \mathrm{~N} \mathrm{NaOH}$ & $9.4 \pm 0.07$ & $3.15 \pm 0.03$ & $23.35 \pm 0.01$ \\
\hline $1 \mathrm{~N} \mathrm{HCl}$ & $6.3 \pm 0.08$ & $8.1 \pm 0.06$ & $10.31 \pm 0.02$ \\
\hline $0.5 \mathrm{~N} \mathrm{HCl}$ & $9.3 \pm 0.01$ & $12.6 \pm 0.04$ & $7.11 \pm 0.01$ \\
\hline $1 \mathrm{~N} \mathrm{NaOH}$ then neutralize with $1 \mathrm{~N} \mathrm{HCl}$ & $8.6 \pm 0.03$ & $22.5 \pm 0.01$ & - \\
\hline $0.5 \mathrm{~N} \mathrm{NaOH}$ then neutralize with $0.5 \mathrm{~N} \mathrm{HCl}$ & $5.6 \pm 0.02$ & $15.3 \pm 0.02$ & - \\
\hline $1 \mathrm{~N} \mathrm{HCl}$ then neutralize with $1 \mathrm{~N} \mathrm{NaOH}$ & $8.6 \pm 0.01$ & $12.6 \pm 0.06$ & - \\
\hline $0.5 \mathrm{~N} \mathrm{HCl}$ then neutralize with $0.5 \mathrm{~N} \mathrm{NaOH}$. & $8.4 \pm 0.05$ & $15.3 \pm 0.03$ & - \\
\hline
\end{tabular}

Results are mean values of three replicates \pm standard deviation

modification. Results were expressed as percentage inhibition of the DPPHC using the following equation:

Inhibition of DPPH $(\%)$ = absorbance control-absorbance sample/absorbance control $\times 100$ where, absorbance control is the absorbance of DPPH solution without extract and butylated hydroxyltoluene (BHT) was used as positive control. Lower absorbance of the reaction mixture indicates higher free radical scavenging activity.

\section{Estimation of $\mathrm{H}_{2} \mathrm{O}_{2}$ scavenging activity}

Hydrogen peroxide exhibits weak activity for initiating lipid peroxidation; however, its potential to produce highly $\mathrm{ROS}$, such as $\mathrm{OH}$ through Fenton reaction, is very high (Ali et al. 2009). The $\mathrm{H}_{2} \mathrm{O}_{2}$ scavenging ability of each extract was determined according to Sfahlan et al. (2009) with some modification. The absorbance value of the reaction mixture was recorded at $230 \mathrm{~nm}$ after $10 \mathrm{~min}$. The BHT (50 $\mu \mathrm{g}$ mlG1) was used as positive control.

\section{Estimation of total reducing capability}

The total reduction capability is the reducing capacity of a compound related to its electron transfer ability and indicator of its antioxidant activity (Meir et al. 1995).

The reducing power of each extract was determined according to (Zhao et al. 2008) with some modifications. The absorbance was measured spectrophotometrically at $700 \mathrm{~nm}$. The measurement was compared to the standard curve of prepared BHT solution. The final results were expressed as milligram of BHT equivalents per gram based on dry weight.

\section{Antibacterial methods}

Agar well diffusion was done by using the modified agar well diffusion method described by Nair and Chando (2005). A sterile 8-mm cork borer was used. The prepared nutrient agar plates were rubbed with the test organisms using sterile swab sticks. The sterile $8-\mathrm{mm}$ cork borer was used to bore a hole on the agar film in the Petri dish and filled with each of the different extract prepared. This was then transferred to the incubator at $37^{\circ} \mathrm{C}$ for $24 \mathrm{~h}$. Antibiotics (norfloxacin (NOR), ciprofloxacin (CIP), levofloxacin (LEV), gentamicin $(\mathrm{CN})$, vancomycin (VA), and nitrofurantoin $(\mathrm{F})$ ) were used as control. In the case of A. flavus, a spore suspension (106 spores/ml) was prepared and $100 \mu \mathrm{l}$ of it was spread on potato dextrose agar (PDA) dishes. After absorption, the cork borer was used to bore. The dishes were incubated for 5 days at $25^{\circ} \mathrm{C}$. Visible inhibition zone around bore was used (Freire et al. 2011).

\section{Results}

\section{Compositions of Egyptian JoH and JaH}

Figures 1 and 2 illustrate the compositions of $\mathrm{JoH}$ and $\mathrm{JaH}$.

The dietary fiber fractions of jojoba hulls (JoH) (Fig. 1) are cellulose $17.29 \%$, hemicellulose $1.34 \%$, lignin $35.29 \%$, neutral detergent fiber (NDF) $54.17 \%$, acid detergent fiber (ADF) 52.83\%, and acid detergent lignin (ADL) $35.54 \%$.

The dietary fiber fractions of jatropha hulls (JaH) (Fig. 2) are cellulose $28.14 \%$, hemicellulose $6.62 \%$, lignin $7.34 \%$, neutral detergent fiber (NDF) $42.30 \%$, acid 


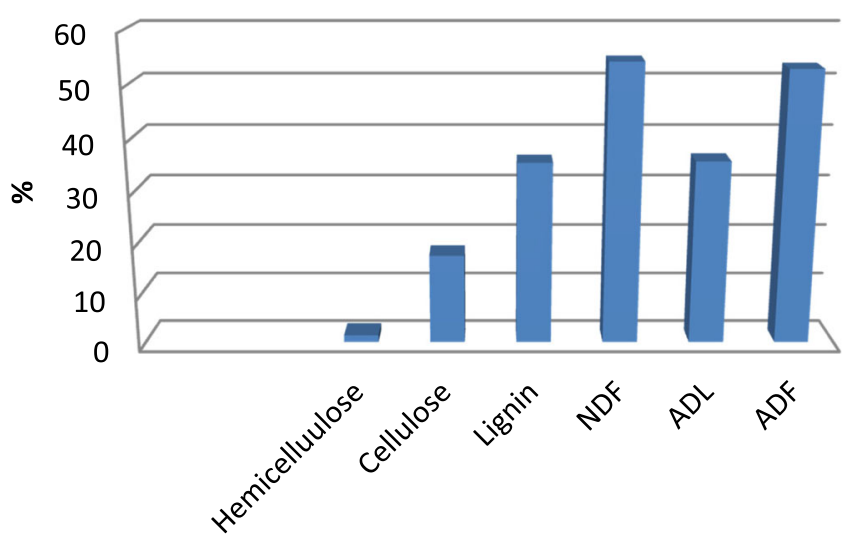

Fig. 1 Dietary fiber composition of jojoba hull. ADF acid detergent fiber, ADL acid detergent lignin, NDF neutral detergent fiber

detergent fiber (ADF) 35.69\%, and acid detergent lignin (ADL) $7.55 \%$.

\section{Total extracted phenolics of $\mathrm{JOH}$ and JAH by different treatments}

In Table 1, total phenolic extract (TPE) from $\mathrm{JoH}$ varied in the different extracts and ranged from $62.0-1.2 \mathrm{mg}$ $\mathrm{g}^{-1}$ dried hulls, and the highest extract yield was obtained by $1 \mathrm{~N} \mathrm{NaOH}$ then neutralized by $1 \mathrm{~N} \mathrm{HCl} 62.0$ $\mathrm{mg} \mathrm{g}^{-1}$ followed by $0.5 \mathrm{~N} \mathrm{NaOH}$ then neutralized by $0.5 \mathrm{~N} \mathrm{HCl}, 1 \mathrm{~N} \mathrm{NaOH}, 0.5 \mathrm{~N} \mathrm{NaOH}$, ethanol: $1 \mathrm{~N} \mathrm{HCl}$ (70:30), ethanol:0.5 $\mathrm{N} \mathrm{HCl}$ (70:30), ethanol: $1 \mathrm{~N} \mathrm{NaOH}$ (70:30), ethanol:0.5 N NaOH (70:30), and finally 1 and $0.5 \mathrm{~N} \mathrm{HCl}$.

Total phenolic extract (TPE) from JaH (Table 2) varied in the different extracts and ranged from 22.9$3.1 \mathrm{mg} \mathrm{g}^{-1}$ dried hulls, and the highest extract yield was obtained by ethanol:0.5 N HCl, followed by ethanol: $1 \mathrm{~N} \mathrm{HCl}, 1 \mathrm{~N} \mathrm{NaOH}, 0.5 \mathrm{~N} \mathrm{NaOH}, 0.5 \mathrm{~N} \mathrm{HCl}$, $1 \mathrm{~N} \mathrm{NaOH}$ then neutralized by $1 \mathrm{~N} \mathrm{HCl}, 1 \mathrm{~N} \mathrm{HCl}$ then neutralized by $1 \mathrm{~N} \mathrm{NaOH}, 0.5 \mathrm{~N}$ HCL neutralized by of $0.5 \mathrm{~N} \mathrm{NaOH}, 1 \mathrm{~N} \mathrm{HCl}, 0.5 \mathrm{~N} \mathrm{NaOH}$ then neutralized by
$0.5 \mathrm{~N} \mathrm{HCl}$, and finally ethanol: $1 \mathrm{~N} \mathrm{NaOH}$ (70:30) and ethanol: $0.5 \mathrm{~N} \mathrm{NaOH}$.

\section{Total flavonoid extract (TFE) of JOH and JAH by different treatment}

Flavonoids, that bear the C6-C3-C6 structure, account for quite half the over 8000 different phenolic compounds. The yield of TFE (Table 1) of JoH ranged between $40 \mu \mathrm{g} \mathrm{g}^{-1}$ and $1.35 \mu \mathrm{gg}^{-1}$ dried hulls, and the highest extract yield of TFE was obtained by $1 \mathrm{~N} \mathrm{NaOH}$ then neutralized by $1 \mathrm{~N} \mathrm{HCl} 40 \mu \mathrm{gg}^{-1}$ followed by $0.5 \mathrm{~N}$ $\mathrm{NaOH}$ then neutralized by $0.5 \mathrm{~N} \mathrm{HCl}, 1 \mathrm{~N} \mathrm{NaOH}, 0.5 \mathrm{~N}$ $\mathrm{NaOH}$, ethanol:0.5 N HCl (70:30), ethanol: $1 \mathrm{~N} \mathrm{HCl}$ (70:30), ethanol: $1 \mathrm{~N} \mathrm{NaOH}$ (70:30), ethanol:0.5 N NaOH (70:30), $1 \mathrm{~N} \mathrm{HCl}$ then neutralized by $1 \mathrm{~N} \mathrm{NaOH}$ and finally $1 \mathrm{~N} \mathrm{HCl}$.

The yield of TFE from JaH ranged between $22.5 \mu \mathrm{g}$ $\mathrm{g}^{-1}$ and $3.15 \mu \mathrm{g} \mathrm{g}^{-1}$ dried hulls, and the highest extract yield of TFE was obtained by $1 \mathrm{~N} \mathrm{NaOH}$ then added equal volume of $1 \mathrm{~N} \mathrm{HCl}$, ethanol: $1 \mathrm{~N} \mathrm{HCl}, 0.5 \mathrm{~N} \mathrm{NaOH}$ then neutralized by $0.5 \mathrm{~N} \mathrm{HCl}, 0.5 \mathrm{~N} \mathrm{HCl}$ neutralized by $0.5 \mathrm{~N} \mathrm{NaOH}$, ethanol:0.5 N HCl, $0.5 \mathrm{~N} \mathrm{HCl}, 1 \mathrm{~N}$

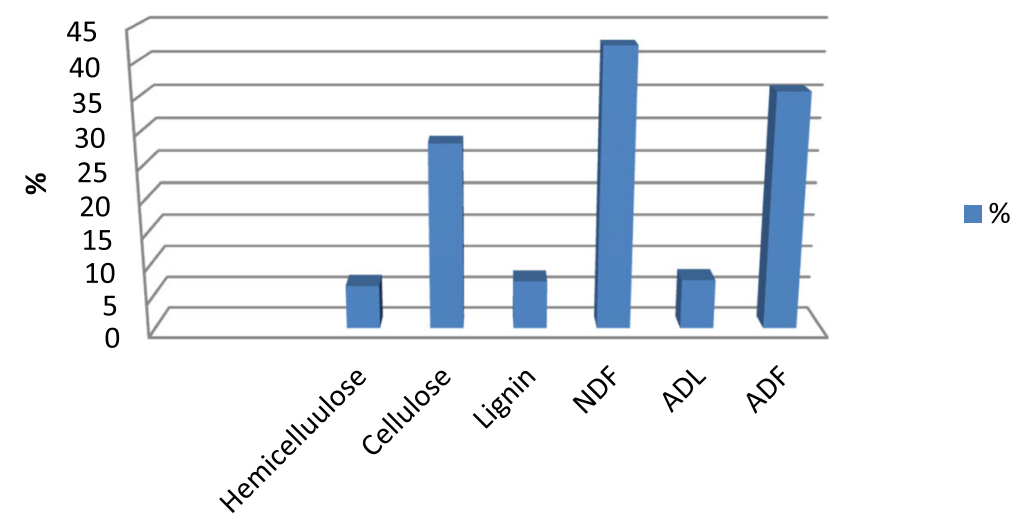

Fig. 2 Dietary fiber composition of jatropha hull. ADF acid detergent fiber, ADL acid detergent lignin, NDF neutral detergent fiber 
$\mathrm{NaOH}$, ethanol:0.5 N NaOH, $1 \mathrm{~N} \mathrm{HCl}$ and finally $0.5 \mathrm{~N}$ $\mathrm{NaOH}$.

\section{Total extracted saponins (TSE) of JoH and JaH by different treatment}

Total extracted saponins (TSE) from JoH ranged from $504.77-115.93 \mu \mathrm{g} \mathrm{g}^{-1}$ dried hulls. It was noticed that $0.5 \mathrm{~N} \mathrm{NaOH}$ have the highest extraction yield followed by $1 \mathrm{~N} \mathrm{NaOH}$ then neutralized by $1 \mathrm{~N} \mathrm{HCl}$ then $1 \mathrm{~N}$ $\mathrm{NaOH}$ ethanol: $1 \mathrm{~N} \mathrm{HCl}$ (70:30), ethanol:0.5 N HCl (70:30), ethanol:1 N NaOH (70:30), ethanol:0.5 N NaOH (70:30), and finally $0.5 \mathrm{~N} \mathrm{NaOH}$ then neutralized by $0.5 \mathrm{~N}$ $\mathrm{HCl}$. Total extracted saponins (TSE) from JAH ranged from 147.1-7.11 $\mu \mathrm{g} \mathrm{g}^{-1}$ dried hulls, and the highest extract yield of TSE was obtained by ethanol:0.5 N HCl, followed by ethanol: $1 \mathrm{~N} \mathrm{HCl}$, ethanol: $0.5 \mathrm{~N} \mathrm{NaOH}$, ethanol: $1 \mathrm{~N} \mathrm{NaOH}, 1 \mathrm{~N} \mathrm{NaOH}, 0.5 \mathrm{~N} \mathrm{NaOH}, 1 \mathrm{~N} \mathrm{HCl}$, and $0.5 \mathrm{~N} \mathrm{HCl}$.

\section{Evaluation of antioxidant activity of JoH and JaH extracts DPPH radical scavenging activity}

Table 3 illustrates the antioxidant activity of jojoba hull extracts at room temperature by the three methods. DPPH radical scavenging activity: The abilities of JoH extracts to scavenge the DPPH radical were found to be in the order of $1 \mathrm{~N} \mathrm{NaOH}$ and $0.5 \mathrm{~N} \mathrm{NaOH}$ with the highest antioxidant activity followed by $0.5 \mathrm{HCl}>1 \mathrm{~N}$ $\mathrm{HCl}>0.5 \mathrm{~N} \mathrm{HCl}$ then neutralized by $0.5 \mathrm{~N} \mathrm{NaOH}>$ ethanol: $0.5 \mathrm{~N} \mathrm{HCl}>$ ethanol: $1 \mathrm{~N} \quad \mathrm{HCl}>0.5 \mathrm{~N} \quad \mathrm{NaOH}$ then added equal volume of $0.5 \mathrm{~N} \mathrm{HCl}>1 \mathrm{~N} \mathrm{NaOH}$ then neutralized by $1 \mathrm{~N} \mathrm{HCl}>\mathrm{BHT}>$ ethanol:0.5 N NaOH then ethanol: $1 \mathrm{~N} \mathrm{NaOH}$.

Table 4 illustrates that the abilities of $\mathrm{JaH}$ extracts to scavenge the DPPH radical was found to be in the order of $1 \mathrm{~N} \mathrm{NaOH}$ and $0.5 \mathrm{~N} \mathrm{NaOH}$ with the highest antioxidant activity followed by $1 \mathrm{~N} \mathrm{HCl}>1 \mathrm{~N} \mathrm{HCl}$ then neutralized by $1 \mathrm{~N} \mathrm{NaOH}>0.5 \mathrm{~N} \mathrm{HCl}$ then neutralized by $0.5 \mathrm{~N} \mathrm{NaOH}>$ ethanol: $1 \mathrm{~N} \mathrm{HCl}>0.5 \mathrm{~N} \mathrm{HCl}>$ ethanol: 0.5 $\mathrm{N} \mathrm{HCl}>0.5 \mathrm{~N} \mathrm{NaOH}$ then neutralized by $0.5 \mathrm{~N} \mathrm{HCl}>1$ $\mathrm{N} \mathrm{NaOH}$ then neutralized by $1 \mathrm{~N} \mathrm{HCl}>\mathrm{BHT}>$ ethanol:0.5 N NaOH then ethanol: $1 \mathrm{~N} \mathrm{NaOH}$.

\section{$\mathrm{H}_{2} \mathrm{O}_{2}$ scavenging activity of $\mathrm{JoH}$ and $\mathrm{JaH}$ extracts}

Jojoba hull extracts (Table 3 ) exhibit the highest values of hydrogen peroxide in the order of $1 \mathrm{~N} \mathrm{NaOH}$ and $0.5 \mathrm{~N}$ $\mathrm{NaOH}>\mathrm{BHT}>$ ethanol:1 N $\mathrm{HCl}>$ ethanol: $1 \mathrm{~N} \quad \mathrm{NaOH}>$ ethanol: $0.5 \mathrm{~N} \mathrm{HCl}>$ ethanol: $0.5 \mathrm{~N} \mathrm{NaOH}>1 \mathrm{~N} \mathrm{HCl}>0.5$ $\mathrm{N} \mathrm{HCl}$. Jatropha hull extracts (Table 4) exhibit the highest values of hydrogen peroxide in the order of $\mathrm{BHT}>$ ethanol: $0.5 \mathrm{~N} \mathrm{NaOH}$ followed by $1 \mathrm{~N} \mathrm{HCl}$ then neutralized by $1 \mathrm{~N} \mathrm{NaOH}>0.5 \mathrm{~N} \mathrm{HCl}>$ ethanol: $1 \mathrm{~N} \mathrm{HCl}>$ ethanol: $0.5 \mathrm{~N}$ $\mathrm{HCl}>0.5 \mathrm{~N} \mathrm{HCl}$ then neutralized by $0.5 \mathrm{~N} \mathrm{NaOH}>0.5 \mathrm{~N}$ $\mathrm{NaOH}>1 \mathrm{~N} \mathrm{HCl}>1 \mathrm{~N} \mathrm{NaOH}>0.5 \mathrm{~N} \mathrm{NaOH}$ then neutralized by $0.5 \mathrm{~N} \mathrm{HCl}>$ ethanol: $1 \mathrm{~N} \mathrm{NaOH}$, and finally $1 \mathrm{~N}$ $\mathrm{NaOH}$ then neutralized by $1 \mathrm{~N} \mathrm{HCl}$.

\section{The reducing power of $\mathrm{JoH}$ and $\mathrm{JaH}$ extracts}

Jojoba hulls extracts showed high reducing capacity with $1 \mathrm{~N} \mathrm{NaOH}$ then added equal volume of $1 \mathrm{~N} \mathrm{HCl}$

Table 3 Antioxidant activity of jojoba hull extracts at room temperature

\begin{tabular}{llll}
\hline $\begin{array}{l}\text { Treatment } 1 \mathrm{~g} \text { meal: } 30 \mathrm{ml} \text { solvent } \\
\text { three times, each time ultrasound } \\
\text { for } 1 \mathrm{~h} \text { then soaking } 24 \mathrm{~h}\end{array}$ & $\begin{array}{l}\text { DPPH scavenging } \\
\text { effect }(\% \pm \mathrm{SD})\end{array}$ & $\begin{array}{l}\text { Hydrogen peroxide scavenging } \\
\text { effect }(\% \pm \text { SD) }\end{array}$ & $\begin{array}{l}\text { Total reductive capability } \\
(\mathrm{m} / \mathrm{g}) \pm \text { SD. }\end{array}$ \\
\hline $\begin{array}{l}\text { Ethanol: } 1 \mathrm{~N} \mathrm{HCl} \\
70: 30\end{array}$ & $87.6 \pm 0.01$ & $13.4 \pm 0.10$ & $15.9 \pm 0.01$ \\
$\begin{array}{l}\text { Ethanol: } 0.5 \mathrm{~N} \mathrm{HCl} \\
70: 30\end{array}$ & $89.4 \pm 0.03$ & $12.0 \pm 0.06$ & $17.0 \pm 0.02$ \\
Ethanol: $1 \mathrm{~N} \mathrm{NaOH}$ & $8.2 \pm 0.02$ & $12.6 \pm 0.05$ & $6.4 \pm 0.04$ \\
$70: 30$ & $43.6 \pm 0.05$ & $11.7 \pm 0.03$ & $9.7 \pm 0.03$ \\
Ethanol:0.5 N NaOH & & $100 \pm 0.01$ & $53.8 \pm 0.1$ \\
$70: 30$ & $100 \pm 0.01$ & $100 \pm 0.01$ & $40.7 \pm 0.07$ \\
$1 \mathrm{~N} \mathrm{NaOH}$ & $100 \pm 0.01$ & $4.9 \pm 0.02$ & $2.4 \pm 0.05$ \\
$0.5 \mathrm{~N} \mathrm{NaOH}$ & $93.9 \pm 0.04$ & $2.2 \pm 0.05$ & $1.3 \pm 0.01$ \\
$1 \mathrm{~N} \mathrm{HCl}$ & $94.8 \pm 0.10$ & $\mathrm{ND}$ & $72.8 \pm 0.20$ \\
$0.5 \mathrm{~N} \mathrm{HCl}$ & $73.6 \pm 0.20$ & $\mathrm{ND}$ & $67.4 \pm 0.10$ \\
$1 \mathrm{~N} \mathrm{NaOH}$ then neutralize with $1 \mathrm{~N} \mathrm{HCl}$ & $77.0 \pm 0.20$ & $\mathrm{ND}$ & $5.7 \pm 0.03$ \\
$0.5 \mathrm{~N} \mathrm{NaOH}$ then neutralize with $0.5 \mathrm{~N} \mathrm{HCl}$ & $87.6 \pm 0.01$ & $\mathrm{ND}$ & 4.42 \\
$1 \mathrm{~N} \mathrm{HCl}$ then neutralize with $1 \mathrm{~N} \mathrm{NaOH}$ & $90.0 \pm 0.07$ & $23.7 \pm 0.4$ & $1.1 \pm 0.1$ \\
$0.5 \mathrm{~N} \mathrm{HCl}$ then neutralize with $0.5 \mathrm{~N} \mathrm{NaOH}$ & $51.5 \pm 0.3$ & &
\end{tabular}


Table 4 Antioxidant activity of jatropha hull extracts at room temperature

\begin{tabular}{|c|c|c|c|}
\hline $\begin{array}{l}\text { Treatment } \\
1 \mathrm{~g} \text { meal: } 30 \mathrm{ml} \text { solvent three times, each time } \\
\text { ultrasound for } 1 \mathrm{~h} \text { then soaking } 24 \mathrm{~h}\end{array}$ & $\begin{array}{l}\text { DPPH scavenging } \\
\text { effect }(\% \pm S D)\end{array}$ & $\begin{array}{l}\text { Hydrogen peroxide scavenging } \\
\text { effect }(\% \pm S D)\end{array}$ & $\begin{array}{l}\text { Total reductive capability } \\
(\mathrm{m} / \mathrm{g}) \pm \mathrm{SD} \text {. }\end{array}$ \\
\hline $\begin{array}{l}\text { Ethanol: } 1 \mathrm{~N} \mathrm{HCl} \\
70: 30\end{array}$ & $91.8 \pm 0.20$ & $14.0 \pm 0.10$ & $4.8 \pm 0.01$ \\
\hline $\begin{array}{l}\text { Ethanol:0.5 N HCl } \\
70: 30\end{array}$ & $90.8 \pm 0.40$ & $13.9 \pm 0.05$ & $54.3 \pm 0.20$ \\
\hline $\begin{array}{l}\text { Ethanol:1 N NaOH } \\
70: 30\end{array}$ & $6.7 \pm 0.05$ & $9.6 \pm 0.02$ & $4.8 \pm 0.02$ \\
\hline $\begin{array}{l}\text { Ethanol:0.5 N NaOH } \\
70: 30\end{array}$ & $13.3 \pm 0.10$ & $15.5 \pm 0.01$ & $4.1 \pm 0.07$ \\
\hline $1 \mathrm{~N} \mathrm{NaOH}$ & $100 \pm 0.01$ & $12.3 \pm 0.20$ & $18.8 \pm 0.03$ \\
\hline $0.5 \mathrm{~N} \mathrm{NaOH}$ & $100 \pm 0.01$ & $13.1 \pm 0.10$ & $11.3 \pm 0.01$ \\
\hline $1 \mathrm{~N} \mathrm{HCl}$ & $94.0 \pm 0.30$ & $12.4 \pm 0.01$ & $19.5 \pm 0.20$ \\
\hline $0.5 \mathrm{~N} \mathrm{HCl}$ & $91.0 \pm 0.02$ & $14.4 \pm 0.30$ & $30.5 \pm 0.10$ \\
\hline $1 \mathrm{~N} \mathrm{NaOH}$ then neutralize with $1 \mathrm{~N} \mathrm{HCl}$ & $82.4 \pm 0.05$ & $1.8 \pm 0.01$ & $16.2 \pm 0.01$ \\
\hline $0.5 \mathrm{~N} \mathrm{NaOH}$ then neutralize with $0.5 \mathrm{~N} \mathrm{HCl}$ & $89.1 \pm 0.01$ & $11.9 \pm 0.04$ & $17.5 \pm 0.08$ \\
\hline $1 \mathrm{~N} \mathrm{HCl}$ then neutralize with $1 \mathrm{~N} \mathrm{NaOH}$ & $94.0 \pm 0.20$ & $14.8 \pm 0.07$ & $31.4 \pm 0.05$ \\
\hline $0.5 \mathrm{~N} \mathrm{HCl}$ then neutralize with $0.5 \mathrm{~N} \mathrm{NaOH}$ & $92.1 \pm 0.01$ & $13.3 \pm 0.05$ & $31.6 \pm 0.02$ \\
\hline BHT & $51.5 \pm 0.3$ & $23.7 \pm 0.4$ & $101 \pm 0.1$ \\
\hline
\end{tabular}

Results are mean values of three replicates \pm standard deviation

followed by $0.5 \mathrm{~N} \mathrm{NaOH}$ then added equal volume of $0.5 \mathrm{~N} \mathrm{HCl}>1 \mathrm{~N} \quad \mathrm{NaOH}>0.5 \mathrm{~N} \quad \mathrm{NaOH}>$ ethanol:0.5 N $\mathrm{HCl}>$ ethanol: $1 \mathrm{~N} \quad \mathrm{HCl}>$ ethanol:0.5 N $\mathrm{NaOH}>$ ethanol: $1 \mathrm{~N} \mathrm{NaOH}>1 \mathrm{~N} \mathrm{HCl}$ then neutralized by $1 \mathrm{~N}$ $\mathrm{NaOH}>0.5 \mathrm{~N} \mathrm{HCl}$ then neutralized by $0.5 \mathrm{~N} \mathrm{NaOH}>$ $1 \mathrm{~N} \mathrm{HCl}$, and finally $0.5 \mathrm{~N} \mathrm{HCl}>\mathrm{BHT}$.

The highest reducing power of jatropha hull extracts, ethanol: $0.5 \mathrm{~N} \mathrm{HCl}>0.5 \mathrm{~N} \mathrm{HCl}$ then added equal volume of $0.5 \mathrm{~N} \mathrm{NaOH}>1 \mathrm{~N} \mathrm{HCl}$ then neutralized by $1 \mathrm{~N}$ $\mathrm{NaOH}>0.5 \mathrm{~N} \quad \mathrm{HCl}>1 \mathrm{~N} \quad \mathrm{HCl}>1 \mathrm{~N} \quad \mathrm{NaOH}>0.5 \mathrm{~N}$ $\mathrm{NaOH}$ then added and neutralized by $0.5 \mathrm{~N} \mathrm{HCl}>1 \mathrm{~N}$ $\mathrm{NaOH}$ then neutralized by $1 \mathrm{~N} \mathrm{HCl}>0.5 \mathrm{~N} \mathrm{NaOH}>$ ethanol: $1 \mathrm{~N} \quad \mathrm{NaOH}$ > ethanol: $0.5 \mathrm{~N} \quad \mathrm{NaOH}>$ ethanol: $1 \mathrm{~N}$ $\mathrm{HCl}$, and finally ethanol:0.5 N NaOH $>\mathrm{BHT}$.

\section{Antimicrobial}

The hull extracts of jojoba and jatropha hull were examined for their antimicrobial activity against common food spoilage and pathogenic bacteria namely B. cereus, E. coli, and A. flavus (Tables 5 and 6). The results of the antibacterial assay showed that gram-positive $B$. cereus was the most sensitive being inhibited by all of the extracts.

\section{Discussion}

This study was planned to investigate phytochemical content, antioxidants, and antibacterial activities of 12 extracts resulting from 12 treatments and to extract the free and bounded bioactive compounds from jojoba and jatropha hulls because in different studies, the extraction of phytochemical is done by using combined methods.
This occurs when a single extraction method is low as we would expect, thus a mixture of extraction processes could be the optimum effective method for extraction of different polyphenols in extracts (Alfredo 2016). According to these reports and to our last study in this field, we used different treatments because as can be seen in the examined hull biomass (Figs 1 and 2), these are composed of cellulose, hemicellulose, lignin, and other minor components. Lignin is a polymer that contains mostly different functional groups involved in its depolymerization and degradation; phenolic compounds possess an aromatic ring bearing one or more hydroxyl groups, and their structures may range from a simple phenolic molecule to a complex high-molecular weight polymer (Balasundram et al. 2006). Since the solubility of bioactive compounds in general is depending on their chemical nature which vary from simple to very highly polymerized substances, the solubility of bioactive compounds is affected by the polarity of the solvent used (Wagdy and Taha 2017). We chose to use ethanol over other alcohols because of its safety, easily separated by evaporation, low boiling points, recycled to lower the costs of the treatments, and should be evaporated before the use of the extracts (Sun and Cheng 2002). Also, we used $70 \mathrm{ml}$ of ethanol (organosolvent) mixed with 30 $\mathrm{ml} \mathrm{HCl}$ or $\mathrm{NaOH}$ with ultrasound-assisted extraction then soaking overnight to reduce the temperature and to enhance the process by hydrolysis of lignin and extracts of the bound phenolic, flavonoid, and saponin compounds without degradations of phenolic compounds, leaving 
Table 5 Antimicrobial effect of jojoba hull extract on the inhibition growth of food born microorganisms

\begin{tabular}{|c|c|c|c|}
\hline \multirow[t]{3}{*}{ Extract types } & \multicolumn{3}{|l|}{ Food born microorganisms } \\
\hline & B. ceruse (EMCC 1080) & E. coli 0157:H7 (ATCC 51659) & A. flavus (ATCC 16872) \\
\hline & Inhibition zone diameter (mm) & Inhibition zone diameter (mm) & Inhibition zone diameter (mm) \\
\hline $\begin{array}{l}\text { Ethanol:1 N HCl } \\
70: 30\end{array}$ & 15.0 & 14.9 & 5.2 \\
\hline $\begin{array}{l}\text { Ethanol:0.5 N HCl } \\
70: 30\end{array}$ & 5.1 & 0.0 & 0.0 \\
\hline $\begin{array}{l}\text { Ethanol:1 N HCl } \\
70: 30\end{array}$ & 5.2 & 0.0 & 0.0 \\
\hline $\begin{array}{l}\text { Ethanol:0.5 N NaOH } \\
70: 30\end{array}$ & 0.0 & 0.0 & 0.0 \\
\hline $1 \mathrm{~N} \mathrm{NaOH}$ & 0.0 & 0.0 & 0.0 \\
\hline $0.5 \mathrm{~N} \mathrm{NaOH}$ & 0.0 & 0.0 & 0.0 \\
\hline $1 \mathrm{~N} \mathrm{HCL}$ & 10.3 & 15.0 & 5.1 \\
\hline $0.5 \mathrm{~N} \mathrm{HCl}$ & 15.1 & 15.6 & 4.8 \\
\hline $1 \mathrm{~N} \mathrm{NaOH}$ then then neutralized by $1 \mathrm{~N} \mathrm{HCl}$ & 15.2 & 10.3 & 5.3 \\
\hline $0.5 \mathrm{~N} \mathrm{NaOH}$ then then neutralized by $0.5 \mathrm{~N} \mathrm{HCl}$ & 0.0 & 0.0 & 0.0 \\
\hline $1 \mathrm{~N} \mathrm{HCL}$ then neutralized by $1 \mathrm{~N} \mathrm{NaOH}$ & 5.0 & 0.0 & 5.0 \\
\hline $0.5 \mathrm{~N} \mathrm{HCl}$ then then neutralized by $0.5 \mathrm{~N} \mathrm{NaOH}$ & 0.0 & 0.0 & 4.5 \\
\hline
\end{tabular}

the residue to be used in other industrial products (Sun and Cheng 2002). Araque et al. (2007) studied the organosolvent acetone water for pretreatment. They found the highest ethanol yield after treatment with $\mathrm{pH}$ 2.0 and $50 \%$ aqueous acetone. For economic reasons, we used ethanol because ethanol has been favored over alcohols with higher boiling points. Ethanol is a common solvent although it hinders hydrolytic enzymes. It should be isolated from the solid fraction before enzymatic hydrolysis (Taherzadeh and Karimi 2007).

The extraction yield of TPE, TFE, and TSE of JoH and $\mathrm{JaH}$ with different treatments starting with:

Table 6 Antimicrobial effect of jatropha hull extract on the inhibition growth of food born microorganisms

\begin{tabular}{|c|c|c|c|}
\hline \multirow[t]{3}{*}{ Extract types } & \multicolumn{3}{|l|}{ Food born microorganisms } \\
\hline & B. ceruse (EMCC 1080) & E. coli 0157:H7 (ATCC 51659) & A. flavus (ATCC 16872) \\
\hline & Inhibition zone diameter (mm) & Inhibition zone diameter (mm) & Inhibition zone diameter (mm) \\
\hline $\begin{array}{l}\text { Ethanol:1 N HCl } \\
70: 30\end{array}$ & 15.0 & 15.7 & 14.9 \\
\hline $\begin{array}{l}\text { Ethanol:0.5 N HCl } \\
70: 30\end{array}$ & 5.0 & 0.0 & 5.3 \\
\hline $\begin{array}{l}\text { Ethanol:1 N HCl } \\
70: 30\end{array}$ & 0.0 & 0.0 & 0.0 \\
\hline $\begin{array}{l}\text { Ethanol:0.5 N NaOH } \\
70: 30\end{array}$ & 0.0 & 20.0 & 15.0 \\
\hline $1 \mathrm{~N} \mathrm{NaOH}$ & 0.0 & 0.0 & 0.0 \\
\hline $0.5 \mathrm{~N} \mathrm{NaOH}$ & 0.0 & 0.0 & 0.0 \\
\hline $1 \mathrm{~N} \mathrm{HCl}$ & 14.8 & 16.2 & 6.1 \\
\hline $0.5 \mathrm{~N} \mathrm{HCl}$ & 5.3 & 6.0 & 16.0 \\
\hline $1 \mathrm{~N} \mathrm{NaOH}$ then then neutralized by $1 \mathrm{~N} \mathrm{HCl}$ & 15.2 & 15.3 & 9.9 \\
\hline $\mathrm{O} .5 \mathrm{~N} \mathrm{NaOH}$ then then neutralized by $0.5 \mathrm{~N} \mathrm{HCl}$ & 15.6 & 5.4 & 5.0 \\
\hline $1 \mathrm{~N} \mathrm{HCl}$ then then neutralized by $1 \mathrm{~N} \mathrm{NaOH}$ & 16.0 & 9.8 & 10.3 \\
\hline $0.5 \mathrm{~N} \mathrm{HCl}$ then neutralized by $0.5 \mathrm{~N} \mathrm{NaOH}$ & 14.7 & 10.2 & 4.8 \\
\hline \multicolumn{4}{|c|}{ B. ceruse (Bacillus ceruse) EMCC 1080, E. coli 0157:H7 (Escherichia coli) (ATCC 51659) EHEC and A. flavus (Aspergillus flavus) ATCC 16872} \\
\hline
\end{tabular}


(A) The hulls were crushed in coffee mill to get a finely grounded hulls appropriate for extraction studies because reduction of size have been very important for treatment processes, and their concept was confirmed by Mais et al. (2002). They noted that milling and fine size are very important for hydrolyses processes (like enzymatic hydrolysis) of lignocellulosic wastes as they increase surface area and pores and decrease the polymerization of cellulose and crystallinity (Taherzadeh and Karimi 2007; Rostagno and Prador 2013).

(B) Ultrasound-assisted extraction was used in this study because it was based on the specific frequencies and mechanical effects to reduce time, solvent, energy, and also fast effective in examined mass with natural phytochemical extraction when compared to other techniques (Rostagno and Prador 2013).

After ultrasound effects, the samples were soaked overnight $(24 \mathrm{~h})$ in the same solvents. According to Rostagno and Prador (2013) which reported that reducing heat increases the extraction yield of antioxidant compounds from hazelnut and during soaking, the examined powder in contact with the solvent for $(20 \mathrm{~h})$ or days, in this time the soluble material will be liberated from the powder sample to the solvent medium at room temperature.

\section{Compositions of Egyptian JoH and JaH}

The composition of both hulls leads to promising industrial and biomedical applications (Onyelucheya et al. 2016). The analysis showed that cellulose and hemicellulose in jatropha are higher than in jojoba, but lignin in jojoba is higher than in jatropha. According to our previous study, jojoba is not important or interesting for industrial applications but very important to produce bioactive compounds with other uses (Wagdy and Taha 2012; Wagdy and Taha 2017; El-Hamidi et al. 2016). Jatropha waste is an excellent feedstock for the production of sugars and 2,3-butanediol, also to obtain high concentration of soluble products, reducing sugars, and others. Pretreatments including the digestibility of lignocellulosic biomass and each pretreatment have its specific effect on lignin, cellulose, and hemicellulose (Faulon et al. (1994). In this study, there is a the utilization of acid or base in mild concentration treatments to extract soluble bioactive compounds from hemicelluloses and lignin which is the most complex natural polymer with phenyl propane units, i.e., p-coumaryl alcohol, coniferyl alcohol, and sinapyl alcohol (Wagdy and Taha 2017). Cowpea hulls were subjected to hydrolysis effects done by $4 \%(v / v)$ sulfuric acid concentrate (Onyelucheya et al. 2016), while the residue is still the excellent source of fermentable sugar and activated carbon which is the main important part in the industries according to Environ and Manage (2009).

\section{Total extracted phenolics of JOH and JAH by different treatments}

The current study used $\mathrm{NaOH}$ and $\mathrm{HCl}$ with two concentrations then neutralized the extracts by adding acid or base to the extracts in order to precipitate $\mathrm{NaCl}$ (from $\mathrm{NaOH}+\mathrm{HCl}$ ) and leaving the bioactive compounds in the soluble form then determined as shown in Tables 1 and 2). We used $\mathrm{HCl}$ and also $\mathrm{NaOH}$. According to Environ and Manage (2009), $1 \mathrm{M}$ sodium hydroxide was used for chemical activation of fine raw $\mathrm{JaH}$ and soaked for 24 $h$ at room temperature, and then the excess $\mathrm{NaOH}$ on the activated carbon particles was removed by immersing it in $1.0 \mathrm{M} \mathrm{HCl}$ solution; we also precipitate the excess of acid or base in some treatments to prepare neutral and soluble bioactive compounds.

Tables 1 and 2 showed that the treatment with ethanol: $\mathrm{HCl}$ gave the highest extraction yield.

The solvents used should be evaporated, condensated, and reused to reduce the costs of the process, and the removal of solvents from the treated cellulose is very necessary (Taherzadeh and Karimi 2008). Organosolvent can be utilized to enhance the treated cellulose for enzymatic hydrolysis and to decompose lignin and also some of the hemicelluloses (Curreli et al. 1997). Acid activation with the thermal treatment of JaH increases surface area, pore size, and surface functional groups, but the varied structure obtained depending on the acid used (Environ and Manage 2009).

Lignin in the lignocellulolytic substances can be extracted from the solvent to use as a source of electricity, generate heat, and other products, due to its high purity and low molecular weight (Curreli et al. 1997; Pan et al. 2005) Lignocellulosic raw material can first be handled with dilute aqueous acid $(0.5-2.5 \mathrm{~N}$ sulfuric acid) with temperature of $100^{\circ} \mathrm{C}$ for hydrolyses of the hemicellulosic fraction and addition of $2 \mathrm{~N}$ sulfuric acid with ethanol $(62.5-87.5 \%)$ to the medium during the delignification of the treated lignocellulose to enhance the medium for dissolving of more than $70 \% \mathrm{w} / \mathrm{w}$ of lignin under the acidic conditions (Taherzadeh and Karimi 2008). The extraction of the bound bioactive compounds increased by the acid hydrolysis with high temperature, but in Table 1, the opposite results were obtained; the alkaline hydrolysis is higher than acid hydrolysis because the lignin in jojoba is higher than in jatropha, so the surface area increases in the order: $\mathrm{HCl}<\mathrm{H}_{2} \mathrm{SO}_{4}<\mathrm{NaOH}<$ Steam $<\mathrm{ZnCl}_{2}$ (Rong 2010). The free and bound bioactive compound contents and antioxidant activities of the extracts were found to be dependent on the extraction solvent mixture used, and these agree with our results (Wagdy and Taha 2012).

In (Tables 1 and 2), these treatments also agree with, the acid in high concentration is a reason for glycosides and acylglycosides hydrolysis and thus may get various pictures of native polyphenol profiles, and not all 
polyphenols exist in the free form. Phenolic acids such as ferulic acid and lignins in grains are often bound to structural materials. Hydrolysis using acid or alkaline releases these phenolics; hydrolysis with strong acid from 2 to $4 \mathrm{M} \mathrm{HCl}$ is carried out to obtain aglycones (Rong 2010). Hydrolysis of flax seed extract by alkaline with $0.1 \mathrm{M}$ sodium hydroxide was chosen than the acidic hydrolysis (Renouard et al. 2010). These pretreatments were chosen by using less severe processing conditions in order to save the bioactive compound, and then the remaining residue can be used in other industrial applications. The treatments with two concentrations of acid or base agree with Taherzadeh and Karimi (2008). Bound phenolics and flavonoids can be extracted by several methods such as acid hydrolysis (Shahidi and Yeo 2016; Jansen et al. 2001).

In some treatments, we used only $\mathrm{NaOH}$ according to Wang et al. (2008) who used alkali pretreatment such as $\mathrm{NaOH}, \mathrm{Ca}(\mathrm{OH})_{2}$ (lime) to remove lignin with some part of the hemicellulose. Alkaline hydrolysis with $0.1 \mathrm{M}$ sodium hydroxide at room temperature from 0 to $48 \mathrm{~h}$. was performed on the medium of lignocellulose and centrifuged for $15 \mathrm{~min}$, and the solid residue was neutralized with acetic acid (Sun et al. 2012). Dilute-acid hydrolysis can be combined with other chemical treatments (Taherzadeh and Karimi 2008).

Results are mean values of three replicates \pm standard deviation.

\section{Total flavonoid extracted (TFE) from JoH and JAH by different treatments}

Flavonoids, that bear the $\mathrm{C} 6-\mathrm{C} 3-\mathrm{C} 6$ structure, account for quite half the over 8000 different phenolic compounds (Shahidi and Yeo 2016).

In this study, the flavonoids were extracted with different treatments which gave different structures as bioactive compounds because of the following reasons: (1) the degree of hydroxylation and the $-\mathrm{OH}$ group position in the $\mathrm{B}$ ring or ortho-dihydroxyl structure of ring $\mathrm{B}$ (catechol group) accepted higher activity; (2) the existence of hydroxyl groups at the 30,40 , and 50 positions of the aromatic ring $\mathrm{B}$ (a pyrogallol group) has been recorded to raise the antioxidant activity (Acker et al. 1996); (3) a double bond between $\mathrm{C}-2$ and $\mathrm{C}-3$, conjugated with the 4-oxo group in ring $\mathrm{C}$, increases the radical scavenging activity (Pietta 2000); (4) a double bond between C-2 and $\mathrm{C}-3$, combined with a $3-\mathrm{OH}$, in ring $\mathrm{C}$ raises the activity; and (5) substitution of hydroxyl groups in ring $\mathrm{B}$ by methoxyl groups ends up in higher activity of flavonoids (Pietta 2000; Seeram and Nair 2002). Flavonoids are more complex in structure and substitution nature on rings $\mathrm{B}$ and $\mathrm{C}$ which is the base of the antioxidant activity of flavonoids. Different oil seeds and other seeds were plentiful of bound flavonoids (Seeram and Nair 2002).

\section{Total extracted saponins (TSE) from JoH and JaH by} different treatments

These results related to the nature of hulls, solvent polarity, and the saponin structure, according to Oleszek and Hamed (2010). It is the complex structure of saponins that undergo chemical transformations (via hydrolysis in the presence of acids/alkali) in the glycosidic linkage which change their properties and biological activity.

Tables 3 and 4 reveal that phenolic compounds and flavonoids exhibited positive effects and strong correlation with antioxidant capacity. Saponins were found to have less correlation with antioxidant capacity in comparison with phenolic compounds and flavonoids. These findings confirm that phenolic compounds including flavonoids were contributors to antioxidant activity of dried $\mathrm{H}$. hirsute L. leaves (Pham et al. 2015) and also were supported by Vuong et al. (2013), the papaya leaf had antioxidant capacity related to its phenolic compounds; in some vegetables, the free phenolic correlated with antioxidant activity (Hung and Duy 2012).

\section{Evaluation of antioxidant activity of $\mathrm{JoH}$ and $\mathrm{JaH}$ extracts}

The extracts of all solvent were evaluated by three methods. Hydrogen peroxide $\left(\mathrm{H}_{2} \mathrm{O}_{2}\right)$ scavenging, (DPPH) radical scavenging, and finally total reducing capability gives indications about the health benefits, functions of foods, and can be determined in lab and compared with synthetic BHT as standard (very stable). Free radicals are used to confirm antioxidant activities in vitro within a relatively short time (Ajiboye et al. 2010).

\section{First $D P P H^{*}$ radical scavenging activity}

Table 3 illustrates the antioxidant activity of JoH extracts at room temperature by the three methods. DPPH radical scavenging activity:

The antioxidant activity of phenolic compounds relays on the substitutions on the aromatic rings, the number and locations of the hydroxyl groups, and also the nature of substitutions on the aromatic rings (Balasundram et al. 2006). However, substitution of $\mathrm{OH}$ groups at the 3 and 5 position with $\mathrm{OCH}_{3}$ as in syringic acid reduces the activity (Rice-Evans et al. 1996).

Tables 3 and 4 illustrate the influence of different solvent on the antioxidant capacity of the treatments which measured by three methods. The highest abilities of antioxidant activity of $\mathrm{JoH}$ and $\mathrm{JaH}$ to scavenge the DPPH radical are $1 \mathrm{~N} \mathrm{NaOH}$ and $0.5 \mathrm{~N} \mathrm{NaOH}$ in addition to most of the treatments that had higher scavenging activities than BHT. The values of phytochemicals present in the extract were confirmed by the results of radical scavenging activity (Sticher 2008). The free radical activity of $J$. curcas leaf extracted in vitro is in line with the results reported by Kamal and Manmohan (2011). In this study, the extracts showed scavenging activity against DPPH and 
total reductive capability higher than the synthetic standard BHT (Tables 3 and 4).

The results showed that all the extraction medium (acidic, basic, or neutral) with or without ethanol influenced on the yield and type of the extract components. In addition, its activities agree with Rao et al. (2014). The $\mathrm{pH}$ effect was studied and total carbohydrates and phenolics extraction were influenced by $\mathrm{pHs}$, ethanol water at $\mathrm{pH} 3$ (acidic), 7 (neutral), and 11 (basic), or $(50 \%)$ sodium hydroxide solution influence on total phenolics were in agreement with those reported by Suparna (2013). They showed that the extraction of free phenolics from flax shives using high $\mathrm{pH}(\mathrm{pH} 13)$ of phosphate buffer $(0.01 \mathrm{M})$ at $230^{\circ} \mathrm{C}$ and pressure is higher than the extraction with water at $\mathrm{pH}$ of 6.8. This is because of the breakage of the lignin and carbohydrate-lignin linkages present (ester and ether linkages or $\mathrm{C}-\mathrm{C}$ bonds). The addition of a polar solvent, such as aqueous ethanol solutions increased the extraction of total phenolics and total carbohydrates (Suparna 2013).

Results in Tables 1 and 2 are supported by prior reports which indicated that phenolic compounds do not correlate with antioxidant percentage measured by DPPH (Rao et al. 2014), and this is because of different mediums of the extracts which results different structures with different function groups. Amarowicz et al. (2000) noted that the extracts from canola and rapeseed (containing phenolic compounds) exhibited a great percentage of DPPH radical. Fu et al. (2014) and Mohdaly et al. (2010) indicated that the percentage of DPPH radical scavenging activity of $\mathrm{JoH}$ and $\mathrm{JaH}$ was active and stronger than BHT (synthetic antioxidants). The DPPH radical scavenging activity showed that $\mathrm{JoH}$ and $\mathrm{JaH}$ are potentially active, the extracts have apparent difference between them, and they noticed stronger power than BHT in the extracts.

\section{$\mathrm{H}_{2} \mathrm{O}_{2}$ scavenging activity of $\mathrm{JoH}$ and $\mathrm{JaH}$ extracts}

These results confirmed that hydrogen peroxide is highly reactive in $1 \mathrm{~N} \mathrm{NaOH}$ and $0.5 \mathrm{~N} \mathrm{NaOH}$ treatments of $\mathrm{JoH}$, and it was active and stronger than another industrial antioxidant BHT. The orders of the other treatments are ethanol:0.5 N NaOH followed by $1 \mathrm{~N} \mathrm{HCl}$ extraction of $\mathrm{JaH}$ and lower than BHT.

This is confirmed by the almond hulls and shells that contain high phenolic compounds that hinder the lipid peroxidation (Ali et al. 2009). The hydrogen peroxide scavenging rates of hulls were more than of the shells in each genotype (Kosem et al. 2007). Cytoprotective and antioxidant activities of methanolic extract from Garcinia mangostana hulls reduced the oxidative damage in ECV304 endothelial cells after $\mathrm{H}_{2} \mathrm{O}_{2}$ exposure.

\section{The reducing power of $\mathrm{JoH}$ and $\mathrm{JaH}$ extracts}

The different extracts showed significant difference and stronger reducing power than BHT. These results showed that BHT can be exchanged by extracts of $\mathrm{JoH}$ and $\mathrm{JaH}$ when utilized as reducing agent and showed good antioxidant potential, and this is in line with the results of pigeon pea hull extracts studied by Kanatt et al. (2011), who noticed that pigeon pea hull extracts had a high antioxidant activity. Also, it has an antibacterial activity against Bacillus cereus. Meir et al. (1995) reported that the reducing power was increased by increasing the phenolic content of extract, and the reducing capacity of a compound may serve as a significant indicator of its antioxidant activity. Sfhalan et al. (2009) showed that different genotypes of almond shells extract phenolic compounds less than that of hulls and could be partially responsible for their advantage. Mung bean hull extract showed low reducing power, but pigeon pea hull extract showed the highest reducing power capacity (Kanatt et al. 2011; Jadhav, et al., 1995). Water and ethanol extracts of fennel seed noticed great antioxidant activity by various methods when judged against BHA and BHT. Oktay et al. (2003) studied ruit hull and shell phenolic extract and concluded that they possess antioxidant activity. The extract can be useful in hindering or reducing the progress of various oxidative stress-related diseases (Sfahlan et al. 2009). The higher activity of the hydroxycinnamic acid might be because of the $\mathrm{CHCH}-\mathrm{COOH}$ group, which ensures higher $\mathrm{H}$-donating capability and radical stabilization than the $-\mathrm{COOH}$ group in the hydroxybenzoic acids (Balasundram et al. 2006).

The three antioxidant methods proved that both $\mathrm{JoH}$ and $\mathrm{JaH}$ extracts have high antioxidant activities, and most of them are higher than of BHT. The results in the current study indicated that hulls have good antioxidant capacity when compared with the synthetic antioxidant butylated hydroxyltoluene (BHT) and could therefore have many applications in food and also in cosmetic and pharmaceutical industry. The antioxidant capacity in the extract showed different value to the phenolic, flavonoid, and saponin compounds in the extract.

\section{Antimicrobial effect of hull extracts of $\mathrm{JoH}$ and $\mathrm{JaH}$ extracts}

In the case of jojoba and jatropha hull extract, gram-negative bacteria are more resistant to polyphenols than gram-positive bacteria, and this is because of the different compositions of cell wall. Also, gram-negative bacteria additionally have an outer cell membrane constituted of lipopolysaccharide, lipoprotein, and phospholipids, which acts as a potential barrier for foreign molecules with high molecular weight (Negi et al. 2003). 
Jojoba hull extracts (ethanol:1 $\mathrm{N} \mathrm{HCl}$ (70:30) and 1 $\mathrm{N} \mathrm{NaOH}$ then neutralize with $1 \mathrm{~N} \mathrm{HCl}$ ) have highly antimicrobial effect; this is due to the reaction between $\mathrm{NaOH}$ and $\mathrm{HCl}$ to form $\mathrm{NaCl}$ which precipitated and phenolic compound increased. Polyphenolic compounds are broadly spread in the plant kingdom (Li et al. 2006). The reports showed that there is a positive relation between total phenolic composition and antibacterial, antioxidant activity in many plant species (Duh et al. (1999). Phenolic compounds in plants are observed as powerful in vitro antioxidants due to their capability to provide hydrogen or electrons and formation of stable radical intermediates (Scalbert et al. 2005).

Jojoba and jatropha hull extracts have antimicrobial effect; this agrees with reports by Upadhyay (2011) who reported that flavonoids are secondary metabolites, which are the most common group of polyphenolic compounds that are found ubiquitously in plants. Also, they have been reported to exhibit activity against gram-positive bacteria Meyer et al. 1997) and Streptococcus mutans (He et al. 2006). Since the hull extracts of jojoba and jatropha have high contents of polyphenol, it can be inferred that the polyphenols are liable for the microbial inhibition (Chakraborty and Mitra 2008). Pereira et al. (2007) reported the anti-microbial capacity of phenolic compounds in plants.

\section{Conclusion}

This study discovers the chemical methods such as organosolvents mixed with acid or base. The best extraction for the evaluations of antioxidants and antibacterial activities of all treatments from jojoba and jatropha hulls was $70 \mathrm{ml}$ ethanol mixed with $30 \mathrm{ml}(1$ or $0.5 \mathrm{~N}) \mathrm{HCl}$ or $\mathrm{NaOH}$. The different effective treatments introduced different bioactive compounds, thus improve process safety and sustainability with more 'extraction yield. Agro-industrial by-products are good sources of phenolic compounds, with the aid of ultrasounds waves (which possess many features, low cost, fast, easy method), to enhance the extraction process in order to the hydrolysis of lignin, extracted bound bioactive compounds, and also the residue used to prepare activated carbons, biogas production, and conversion of carbohydrate into more simple sugars. Finally, this work will use these extraction methods with various treatments in many advantageous fields such as food additives, phytomedicines, and other industrial applications.

\section{Acknowledgements}

The facilities offered to the authors by the Central Library at the National Research Centre, Cairo, Egypt, to collect the data of article are highly appreciated.

\section{Funding}

The authors thankfully acknowledge the financial assistance of NRC which supports our study.
Availability of data and materials

Not applicable.

\section{Authors' contributions}

EMA worked on the experimented part, SMA worked on the antimicrobial part, and FST, SSM, SMW, and EMA worked on collecting the data and written, read, and approved the final manuscript.

Ethics approval and consent to participate

Not applicable.

\section{Consent for publication}

Not applicable.

Competing interests

The authors declare that they have no competing interests.

\section{Publisher's Note}

Springer Nature remains neutral with regard to jurisdictional claims in published maps and institutional affiliations.

\section{Author details}

'Department of Fats and Oils, National Research Centre, Dokki, Cairo, Egypt. 2Department of Dairy science, National Research Centre, Dokki, Cairo, Egypt.

Received: 21 December 2018 Accepted: 17 January 2019

Published online: 06 February 2019

\section{References}

Acker VSA, van den Berg D-J, Tromp MNJL, Griffioen DH, van Bennekom WP, van der Vijgh WJF et al (1996) Structural aspects of antioxidant activity of flavonoids. Free Radic Biol Med 20:331-342

Ajiboye TO, Salau AK, Yakubu MT, Oladiji AT, Akanji M a, Okogun II (2010) Acetaminophen perturbed redox homeostasis in Wistar rat liver: protective role of aqueous Pterocarpus osun leaf extract. Drug Chem Toxicol 33:77-87

Alfredo, Aires (2016) Phenolics in Foods: Extraction, Analysis and Measurements Alfredo Aires Additional information is available at the end of the chapter Provisional chapter @ 2016 chapter 3, 61-88. https://doi.org/10.5772/66889

Amarowicz R, Naczk M, Shahidi F (2000) Antioxidant activity of various fractions of non-tannin phenolics of canola hulls. J Agric Food Chem 48:2755-2759

Araque E, Parra C, Freer J, Contreras D, Rodriguez J, Mendonca R, Baeza J (2007) Evaluation of organosolv pretreatment for the conversion of Pinus radiata D. Don to ethanol. Enzyme MicrobTech 43:214-219

Balasundram N, Sundram K, Samman S (2006) Phenolic compounds in plants and agri-industrial by-products: antioxidant activity, occurrence, and potential uses Food Chem 99(1):191-203 https://doi.org/10.1016/j.foodchem.2005.07.042

Blois MS (1958) Antioxidant determinations by the use of a stable free radical. Nature 181:1199-1200

Chakraborty M, Mitra A (2008) The antioxidant and antimicrobial properties of the methanoic extract from Cocos nucifera mesocarp. Food Chem 107:994-999

Curreli N, Fadda MB, Rescigno A, Rinaldi AC, Soddu G, Sollai F, Vaccargiu S, Sanjust E, Rinaldi A (1997) Mild alkaline/oxidative pretreatment of wheat straw. Process Biochem 32:665-670

De Ancos B, Sgroppo S, Plaza L, Cano MP (2002) Possible nutritional and healthrelated value promotion in orange juice preserved by high-pressure treatment. J Sci Food Agric 82:790-796

Duh PD, Tu YY, Yen GC (1999) Antioxidant activity of water extract of Harng Jyur (Chrysanthemum morifolium Ramat). Lebensmittel-Wissenscahaft und Technologie 32:269-277

El-Hamidi M, Taha FS, El-Shami SM, Hassanein MM (2016) Use of carbonized seed hulls as alternative to bleaching clay during miscella bleaching of oils. Am J Food Technol 11:12-20

Faulon J, Carlson GA et al (1994) A three-dimensional model for lignocellulose from gymno-spermous wood. Org Geochem 21:1169-1179

Freire MM, Jham GN, Dhingra OD, Jardim CM, Barcelos RC, Valente VMM (2011) Composition, antifungal activity and main fungitoxic components of the essential oil of Mentha piperita L. J Food Safety 32:29-36

Fu R, Zhang Y, Gue Y, Liu F, Chen F (2014) Determination of phenolic contents and antioxidant activities of extracts of Jatropha curcas L. seed shell, abyproduct, a new source of natural antioxidant. Ind Crops Pro 58:265-270 
Harmsen PFH, Huijgen WJJ, Bermúdez López LM, Bakker RRC (2010) Literature review of physical and chemical pretreatment processes for lignocellulosic biomass. Food Biobased Res Biosynergy 1:49 https://www.ecn.nl/docs/library/ report/2010/e10013.pdf

He J, Chen L, Heber D, Shi W, Lu OY (2006) Antibacterial compounds from Glycyrrhiza uralensis. Indian J Nat Prod 69(1):121-124

Hiai S, Nakajima T (1976) Color reaction of some sapogenins and saponins with vanillin and sulfuric acid. Planta Med 29:116-122

Hung PV, Duy TL (2012) Effects of drying methods on bioactive compounds of vegetables and correlation between bioactive compounds and their antioxidants. Int Food Res J 19:327-332 Google Scholar

Jadhav SJ, Nimbalkar SS, Kulkarni AD, Madhavi DL (1995) Lipid Oxidation in Biological and Food Systems. In: Food Antioxidants: Technological, Toxicological and Health Perspectives, USA., pp: 5-63.

Jansen MA, van den Noort RE, Tan MY, Prinsen E, Lagrimini LM, Thorneley RN (2001) Phenol-oxidizing peroxidases contribute to the protection of plants from ultraviolet radiation stress. Plant Physiol 126:1012-1023

Kamal S, Manmohan S, Birendra S (2011) A review on chemical and medicobiological applications of Jatropha curcas. Int Res J Pharmacy IRJP 2(4):61-66 http://www.irjponline.com

Kanatt SR, Arjun K, Sharma A (2011) Antioxidant and antimicrobial activity of legume hulls. Food Res Int 44:3182-3187

Kosem N, Han YH, andMoongkarndi P (2007) Antioxidant and cytoprotective activities of methanolic extract from Garcinia mangostana hulls. Sci Asia 33:283-292

Kua SF, Ibrahim J, Ooi CKW, Nan Kl, Hashim N, Yusof HM (2015) Optimisation of phenolic extraction and quantification of phenolics in palm kernel cake. Renewable Biores, 2052-6237-3-2. https://doi.org/10.7243/2052-6237-3-2

Li BB, Smith B, Hossain MM (2006) Extraction of phenolic from citrus peels. I solvent extraction method. Sep Purif Technol 48:182-188

Mais U, Esteghlalian AR, Saddler JN, Mansfield SD (2002) Enhancing the enzymatic hydrolysis of cellulosic materials using simultaneous ball milling. Appl Biochem Biotechnol 98:815-832

Meir S, Kanner J, Akiri B, Philosoph-Hadas S (1995) Determination and involvement of aqueous reducing compounds in oxidative defense systems of various senescing leaves. J Agric Food Chem 43:1813-1819

Meyer JJM, Afolayan AJ, Taylor MB, Erasmus D (1997a) Antiviral activity of galangin from the aerial parts of Helichrysum aureonitens. J Ethnopharmacol 56:165-169 https://www.ncbi.nlm.nih.gov/pubmed/9174978

Mohammad M (2010) Studies on the adsorption of heavy metal ions and dye from aqueous solution using physic seed hull (Jatropha curcas L.). Ph.D. thesis. University Teknologi Petronas, Perak

Mohammad M, Yaakob Z, Abdullah SRS (2013) Carbon derived from Jatropha seed hull as a potential green adsorbent for cadmium (II) removal from waste water. J Mater 6(10):4462-4478

Mohdaly AA, Sarhan MA, Smetanska I, Mahmoud A (2010) Antioxidant properties of various solvent extracts of potato peel, sugar beet pulp and sesame cake. J Sci Food Agric 90:218-226

Nair R, Chando SA (2005) Anticandidal activity of Punica granatum exhibited in different solvents. Pharmacol Biol 42:21-25

Negi PS, Jayaprakasha GK, Jena BS (2003) Antioxidant and antimutagenic activities of pomegranate peel extracts. Food Chem 80:393-397

Oktay M, Gulcin I, Kufrevioglu OI (2003) Determination of in vitro antioxidant activity of fennel (Foeniculum vulgare) seed extracts. LWT-Food Sci Technol 36:263-271

Olajire AA, Azeez L (2011) Total antioxidant activity, phenolic, flavonoid and ascorbic acid contents of Nigerian vegetables. Afr J Food Sci Technol 2(2): 022-029

Oleszek W, Hamed A (2010) Saponin-based surfactants. In: Kjellin M, Johansson (eds) Surfactants from renewable resources. Wiley. https://doi.org/10.1002/ 9780470686607.ch12

Oloyede OB, Salau AK, Akeusola RT, Ganiyu OT, Azeez L, Ogunbode SM (2012) Phytochemical content, radical scavenging and antibacterial properties of aqueous extract of Jatropha curcas Linn leaves. Fountain J Nat Appl Sci 1(1):41-48

Onyelucheya CM, Nwabanne TJ, Onyelucheya OE, Onuoha OE (2016) Dilute acid hydrolysis of cowpea hulls: a kinetic study. J Adv Sci Eng 6(4):451-455. https://doi.org/10.18517/ijaseit.6.4.866

Pan X, Arato C, Gilkes N, Gregg D, Mabee W, Pye K, Xiao Z, Zhang X, Saddler J (2005) Biorefining of softwoods using ethanol organosolv pulping: preliminary evaluation of process streams for manufacture of fuel-grade ethanol and co-products. Biotechnol Bioeng 90:473-481
Pereira JA, Oliveira I, Sousa A, Valentao P, Andvade PB (2007) Walnut (Juglaus regia $\mathrm{L}$ ) leaves: phenolic compounds, antibacterial activity and antioxidant potential of different cultivars. Food Chem Toxicol 45: 2285-2295

Pham HNT, Vuong QV, Nguyen VT, Bowyer MC, Scarlett CJ (2015) Effect of extraction solvents and drying methods on the physicochemical and antioxidant properties of Helicteres hirsuta Lour leaves. J Technol 3: 285-301

Pietta PG (2000) Flavonoids as antioxidants. J Nat Prod 63:1035-1042

Pingret D, Tixier AF, andChemat F (2013) Ultrasound-assisted extraction. The Royal Society of Chemistry CHAPTER 3. In: Natural Product Extraction Principles and Applications. on https://pubs.rsc.org. https://doi.org/10.1039/ 9781849737579-00089

Rao SF, Zhang Y, Guo Y, Liu F, Chen F (2014) Determination of phenolic contents and antioxidant activities of extracts of Jatropha curcas L. seed shell, a by-product, a new source of natural antioxidant. Ind Crop Prod 58:265-270

Renouard S, Hano C, Corbin C, Fliniaux O, Lopez T, Montguillon J, Barakzoy E, Mesnard F, Lamblin F, Lainé E (2010) Cellulase-assisted release of secoisolariciresinol from extracts of flax (Linum usitatissimum) hulls and whole seeds. J Food Chem 122:679-687

Rice-Evans CA, Miller NJ, Paganga G (1996) Structure-antioxidant activity relationships of flavonoids and phenolic acids. Free Radic Biol Med 20: 933-956

Rong T (2010) Chemistry and biochemistry of dietary polyphenols review. Nutrients 2:1231-1246. https://doi.org/10.3390/nu2121231

Rostagno A, Prador JM (2013) An evaluation of multipurpose wast oil seed hulls for industrial uses. Afr J Biotechnol 11(53):11547-11551. https://doi.org/10. 1039/9781849737579-FP001

Scalbert A, Manach C, Morand C, Remesy C, Jimenez L (2005) Dietary ployphenols and the prevention of diseases. Crit Rev Food Sci Nutr 45:287-306

Schieber A, Stintzing FC, Carle R (2001) By-products of plantfood processing as a source of functional compounds-recent developments. Trends Food Sci Technol 12:401-413

Seeram NP, Nair MG (2002) Inhibition of lipid peroxidationand structure-activity related studies of the dietary constituentsanthocyanins, anthocyanidins, and catechins. J Agric Food Chem 50:5308-5312

Sfahlan AJ, Mahmoodzadeh A, Hasanzadeh A, Heidari R, Jamei R (2009) Antioxidants and antiradicals in almond hull and shell (Amygdalus communis L.) as a function of genotype. Food Chem 115:529-533

Shahidi F, Yeo JD (2016) Insoluble-bound phenolics in food. Molecules 21(9): 1216. https://doi.org/10.3390/molecules21091216

Sticher O (2008) Natural product isolation. Royal Soc Chem 25:517-554. https:// doi.org/10.1039/B700306B

Sun L, Zhang H, Zhuang YL (2012) Preparation of free, soluble conjugate, and insoluble-bound phenolic compounds from peels of Rambutan (Nephelium lappaceum) and evaluation of antioxidant activities in vitro. J Food Sci 77(2): 198-204

Sun Y, Cheng J (2002) Hydrolysis of lignocellulosic materials for ethanol production: a review. Bioresour Technol 83:1-11

Suparna, Sarkar. (2013) Extraction of Carbohydrates and Phenolics. from Barley Hull using Pressurized/Subcritical Fluids in Bioresource and Food Engineering

Taherzadeh MJ, Karimi K (2007) Enzymatic-based hydrolysis processes for ethanol from lignocellulosic materials: a review. BioResources 2:707-738

Taherzadeh MJ, Karimi K (2008) Pretreatment of lignocellulosic wastes to improve ethanol and biogas production: a review. Int J Mol Sci 9(9): $1621-1651$

Upadhyay RK (2011) Plant natural products: their pharmaceutical potential against disease and drug resistant microbial pathogens. J Pharm Res 4(4): 1179-1185 https://www.researchgate.net/publication/236639807 5790ed661797f9.41033253

Vuong QV, Hirun S, Roach PD, Bowyer MC, Phillips PA, Scarlett CJ (2013) Effect of extraction conditions on total phenolic compounds and antioxidant activities of Carica papaya leaf aqueous extracts. J Herb Med 3:104-111

Wagdy SM, Taha FS (2012) Primary assessment of the biological activity of jojoba hull extracts. Life Sci J 9(2):244-253. (ISSN: 1097-8135). http:// www.lifesciencesite.com. 39. https://doi.org/10.7537/marslsj090212.39

Wagdy SM, Taha FS (2017) and Omar S. S. Treatment of jojoba and jatropha seeds hulls wastes and production of new value added products. Am J Food Technol 12(2):96-105 
Wang KL, Sun Y, Salazar XS, Hohn JM (2008) Enzymatic hydrolysis of soybean hulls using dilute acid and modified steam-explosion pretreatments. J Biobaased Mater Bioenergy 2(1):43-50

Zhao H, Fan W, Dong J, Lu J, Chen J et al (2008) Evaluation of antioxidant activities and total phenolic contents of typical malting barley varieties. Food Chem 107:296-304

Submit your manuscript to a SpringerOpen ${ }^{\odot}$ journal and benefit from:

- Convenient online submission

- Rigorous peer review

- Open access: articles freely available online

- High visibility within the field

- Retaining the copyright to your article

Submit your next manuscript at $\boldsymbol{\wedge}$ springeropen.com 